\title{
Low dosages of vitamin A may cause a decrease in the total neuron number of fetal hippocampal rat cells
}

\author{
Ay $\mathrm{H}^{1}$, Aslan $\mathrm{D}^{1}$, Soztutar $\mathrm{E}^{2}$, Yucel $\mathrm{F}^{1}$ \\ Department of Anatomy, Faculty of Medicine, Eskisehir Osmangazi University, Eskisehir, Turkey. \\ hakanay@ogu.edu.tr
}

\begin{abstract}
OBJECTIVES: We investigated the effect of low, medium and high doses of oral vitamin A, on the number of fetal hippocampal neurons.

BACKGROUND: High doses of vitamin A during pregnancy may cause embryonic malformations. There are reports about dosages that don't cause macroscopic malformations, but may cause mental and behavioral disorders. Still, quantitative morphological studies explaining this topic are lacking.

METHODS: We administered oral vitamin A to pregnant rats on the 10th-12th days of pregnancy at doses of $10000,20000,30000,40000,50000,100000$ and $200000 \mathrm{IU} / \mathrm{kg}$. We collected the fetuses on the 19th day and removed their brains. After staining with cresyl violet and immunolabeling with Tunel and Ki67 antibody, we examined the hippocampi with stereological methods.

RESULTS: Vitamin A decreased hippocampal neuron numbers beginning from $20000 \mathrm{IU} / \mathrm{kg}$. While the number of Ki67 positive cells increased with the dosage, the increase of apoptotic cells begun at the dose of $50000 \mathrm{IU} / \mathrm{kg}$.

CONCLUSION: Our study demonstrates that vitamin A, beginning from the dosage of $20000 \mathrm{IU} / \mathrm{kg}$, is

decreasing the total hippocampal neuron numbers during the critical period of embryonic brain development and that apoptosis may not be the only factor in this outcome (Tab. 1, Fig. 3, Ref. 27). Text in PDF www.elis.sk KEY WORDS: vitamin A, hippocampus, neuron number, stereology.
\end{abstract}

\section{Introduction}

The concept that vitamins are only beneficial and have no harm seems to lose its validity for many vitamins. Among these, vitamin A is one of the most studied substances that enter the embryo (1). Although vitamin A is essential for survival and development, its high doses are teratogenic (2).

Vitamin A is very effective in the development of the central nervous system (CNS) and often controls it by its oxidation. This control is in the form of induction of neurogenesis and the shaping of the CNS (3). The metabolic active form of vitamin A is alltrans retinoic acid (RA). RA binds to the RA receptor (RAR) in the nucleus. (4). Early developmental stages of the forebrain are one of the least studied subjects, there is not much data on the effect of RA on the forebrain $(5,6)$. The hippocampus, that develops from the forebrain, has an important place in studies related to vitamin A and its derivates (retinoids) because of its role in learning and memory and because of the presence of dense RAR's in this region

${ }^{1}$ Department of Anatomy, Faculty of Medicine, Eskisehir Osmangazi University, Eskisehir, Turkey, and ${ }^{2}$ Department of Anatomy, Faculty of Medicine, Yeditepe University, Istanbul, Turkey.

Address for correspondence: $\mathrm{H}$. Ay, Department of Anatomy, Faculty of Medicine, Eskisehir Osmangazi University, Eskisehir, Turkey. Phone: +902222392979/4431, Fax: +902222393772

Acknowledgement: This work has been supported by ESOGU-Commission of Scientific Research Projects (2016-1217 to Hakan AY). even in adult individuals (7). High concentrations of RA reduce the number of hippocampal neurons in cell culture (8). Because of the lack of sufficient in vivo studies, this study will focus on the morphological effects of vitamin A on the fetal hippocampus.

There are clinical reports that concluded that daily dosages of above 10000 IU/day may cause malformation in the CNS (9). Dose of RA that causes no large morphological malformations $(2.5 \mathrm{mg}$ / $\mathrm{kg}$ ), administered toward the end of the first month of pregnancy in mammals, is impairing the intelligence of pups (10). Consequently, the role of retinoids in CNS function was a focal point in recent years (11). Previous studies have shown that exposure to retinoids during pregnancy may lead to disturbances in learning and other behavioral parameters, even if they're at non-teratogenic doses (subteratogenic) ( $\leq 100000 \mathrm{IU} / \mathrm{kg}$ ) (1). Thus, some studies emphasize the need to track retinoid levels during pregnancy (12).

While there are clinical, behavioral and immunohistochemical studies of subteratogenic dosages (13); there are not enough quantitative studies that could explain the effect of these dosages of vitamin A. Our study aimed to show the effects of orally administered dosages of vitamin A on the fetal hippocampus using immunohistochemical and stereological methods.

\section{Materials and methods}

We brought 40 female Sprague-Dawley albino rats from the Eskisehir Osmangazi University Animal Care Facility. After over- 
Tab. 1. Table summarizing the mean values of stereological measurements with \pm standard deviation (SD). We evaluated seven fetal brains from each group.

\begin{tabular}{|c|c|c|c|c|c|c|c|c|}
\hline Dosages IU/kg & 0 & 10000 & 20000 & 30000 & 40000 & 50000 & 100000 & 200000 \\
\hline Total Hippocamp & $98329 \pm 1239$ & $101139 \pm 2121$ & $87843 \pm 1331$ & $86905 \pm 1333$ & $87789 \pm 5413$ & $87522 \pm 2052$ & $72871 \pm 2155$ & $53933 \pm 2852$ \\
\hline cells $\left(\mathrm{mm}^{-2}\right)$ & $39.8 \pm 3.5$ & $39.5 \pm 5.9$ & $39.6 \pm 2.9$ & $44.1 \pm 3.4$ & $45.4 \pm 5.6$ & $54.9 \pm 2.1$ & $60.4 \pm 3.6$ & $57.3 \pm 4.1$ \\
\hline Ki67 + cells $\left(\mathrm{mm}^{-2}\right)$ & $223.6 \pm 13.4$ & $346.0 \pm 11.9$ & $342.9 \pm 6.4$ & $326.8 \pm 31.4$ & $262.2 \pm 18.9$ & $285.4 \pm 3.3$ & $255.4 \pm 9.2$ & $215.0 \pm 6.4$ \\
\hline
\end{tabular}

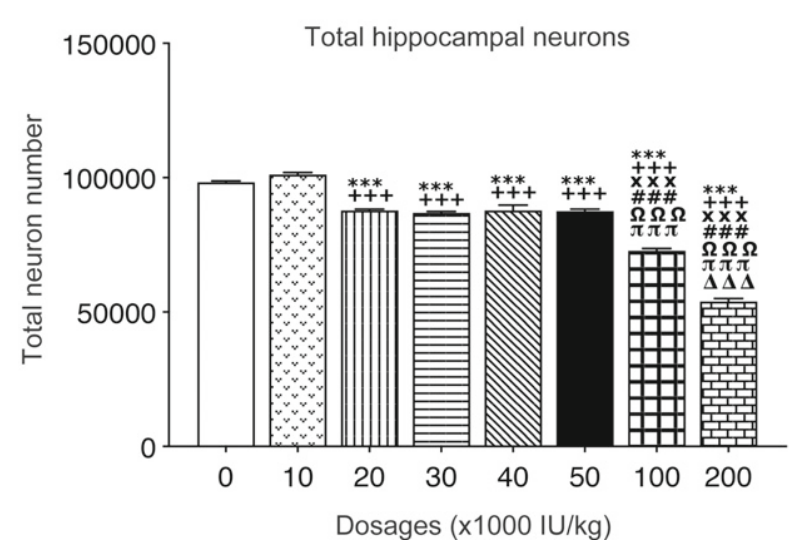

Fig. 1. Graph representing total hippocampal neuron numbers and statistical significances between groups. Error bars are representing SEM. Comparison of control group with other groups, *; Comparison of $10000 \mathrm{IU} / \mathrm{kg}$ group with higher doses, +; Comparison of 20000 $\mathrm{IU} / \mathrm{kg}$ group with higher doses, $\mathrm{x}$; Comparison of $30000 \mathrm{IU} / \mathrm{kg}$ group with higher doses, \#; Comparison of $40000 \mathrm{IU} / \mathrm{kg}$ group with higher doses, $\Omega$; Comparison of $50000 \mathrm{IU} / \mathrm{kg}$ group with higher doses, $\pi$; The comparison of the $100000 \mathrm{IU} / \mathrm{kg}$ group with $200000 \mathrm{IU} / \mathrm{kg}$ dose is shown by $\Delta$. One symbol means $p<0.05$, two means $p<0.01$, three means $\mathrm{p}<0.001$.

night mating with male rats, we considered females with sperms in their vaginal smears as pregnant (G0) and divided the pregnant rats into eight equal groups comprising five rats. Between G10-12, the period where the CNS is most affected by retinoids (14), seven groups received $10000 \mathrm{IU} / \mathrm{kg}, 20000 \mathrm{IU} / \mathrm{kg}, 30000 \mathrm{IU} / \mathrm{kg}, 40000$ $\mathrm{IU} / \mathrm{kg}, 50000 \mathrm{IU} / \mathrm{kg}, 100000 \mathrm{IU} / \mathrm{kg}$ and $200000 \mathrm{IU} / \mathrm{kg}$ of oral vitamin A (retinyl palmitate-Merck) diluted in corn oil, respectively. The control group received only $0.5 \mathrm{ml}$ of corn oil on these days. At G19 we anesthetized the pregnant rats with Halothane. Before scarification with exsanguination, we removed their fetuses via csections. After macroscopic evaluation, we fixed the fetuses with cardiac perfusion (Paraformaldehyde $4 \%$-Merck with Peristar Pro Perfusor). Afterwards we removed the brains of the fetuses, and post fixated them for 24 hours. We embedded the fetal brains in paraffin (Merck) and took $30 \mu \mathrm{m}$ thick sections with a rotary microtome (Leica RM 2125RT) and stained these sections with cresyl violet (CV; Atom Scientific). We evaluated all sections with a Leica DM3000 microscope coupled to a Stereoinvestigator (MBF) unit to estimate the total hippocampal neuron numbers by using the optical fractionator method (15). We used the same paraffin blocks for immunohistochemical staining. For this purpose, we cut every 10th and 11 th section in $10 \mu \mathrm{m}$ and stained them with immunohistochemical techniques. We marked the 10th sections with a Ki67 (Abcam) and the 11th sections with a Tunnel (Abcam) kit to esti- mate the number of immunopositive cells per unit area $\left(\mathrm{N}_{\mathrm{A}}\right)$ of the hippocampus $(16,17)$.

We performed all experimental procedures by protocols approved by the Eskişehir Osmangazi University Local Ethics Committee on Animal Experiments (Protocol \#2016/465-1).

\section{Results}

\section{Morphological examination}

CV stained samples revealed that the hippocampus of nineteenday rat fetuses was not fully developed. The still-developing Ammon's horn was visible, the developing CA1 region distinguishable. Medially to the Ammon's horn was a thick layer of Ammon's horn neuroepithelium followed by subicular neuroepithelium. We could recognize the primordial dentate gyrus, and also the Fimbria extending into the lateral ventricle. We made all identifications on the sections according to the atlas of Altman and Bayer (18).

\section{Stereological findings}

We found no difference between the number of neurons in the control group and the number of neurons in the $10000 \mathrm{IU} / \mathrm{kg}$ group. Total neuron numbers of the other groups were significantly lower than the controls. We saw that the $200000 \mathrm{IU} / \mathrm{kg}$ group had the lowest neuron number and the $100000 \mathrm{IU} / \mathrm{kg}$ group had followed it. There was also a significant difference between these two groups. The $20000 \mathrm{IU} / \mathrm{kg}, 30000 \mathrm{IU} / \mathrm{kg}, 40000 \mathrm{IU} / \mathrm{kg}$ and $50000 \mathrm{IU} / \mathrm{kg}$

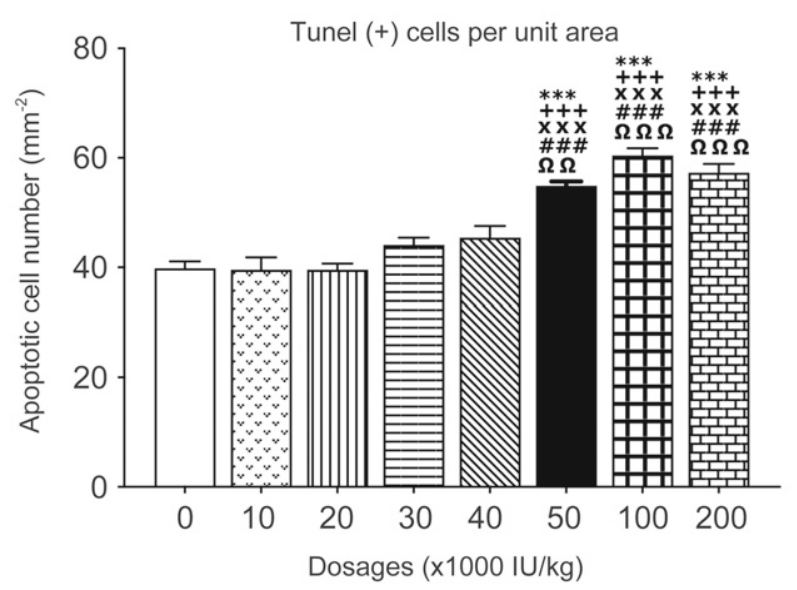

Fig. 2. Graph representing numbers of hippocampal Tunel (+) cells $\left(\mathrm{N}_{\mathrm{A}}\right)$ estimated in unit area. Error bars are representing SEM. Comparison of control group with other groups, *; Comparison of 10000 IU/kg group with higher doses, +; Comparison of $20000 \mathrm{IU} / \mathrm{kg}$ group with higher doses, $\mathrm{x}$; Comparison of $30000 \mathrm{IU} / \mathrm{kg}$ group with higher doses, \#; Comparison of $40000 \mathrm{IU} / \mathrm{kg}$ group with higher doses, $\Omega$. One symbol means $p<0.05$, two means $p<0.01$, three means $p<0.001$. 
580-583

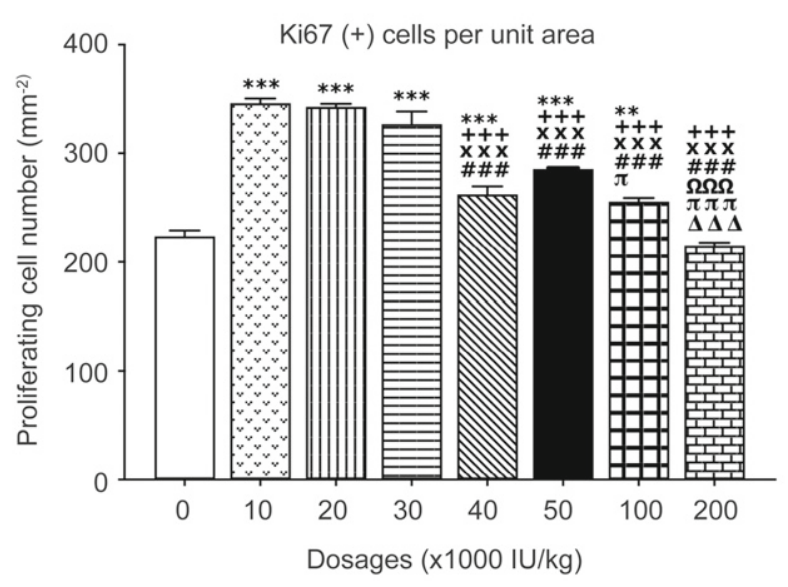

Fig. 3. Graph representing numbers of hippocampal Ki67(+) cells $\left(N_{A}\right)$ estimated in unit area. Error bars are representing SEM. Comparison of control group with other groups, *; Comparison of $10000 \mathrm{IU} / \mathrm{kg}$ group with higher doses, +; Comparison of $20000 \mathrm{IU} / \mathrm{kg}$ group with higher doses, $\mathrm{x}$; Comparison of $30000 \mathrm{IU} / \mathrm{kg}$ group with higher doses, \#; Comparison of 40000 IU/kg group with higher doses, $\Omega$; Comparison of $50000 \mathrm{IU} / \mathrm{kg}$ group with higher doses, $\pi$; The comparison of the $100000 \mathrm{IU} / \mathrm{kg}$ group with $200000 \mathrm{IU} / \mathrm{kg}$ dose is shown by $\Delta$. One symbol means $p<0.05$, two means $p<0.01$, three means $p<0.001$.

dosages were not different between each other and control; their neuron numbers were less than controls, but significantly higher than the $100000 \mathrm{IU} / \mathrm{kg}$ and $200000 \mathrm{IU} / \mathrm{kg}$ groups (Fig. 1, Tab. 1).

The calculations of Tunel positive cells revealed that the number per unit area of these cells increased as the dosage increased. But we found no difference between the groups beginning from the control group up to the dosage of $40000 \mathrm{IU} / \mathrm{kg}$. There was no significant difference in the number of apoptotic cells between the $50000 \mathrm{IU} / \mathrm{kg}, 100000 \mathrm{IU} / \mathrm{kg}$ and $200000 \mathrm{IU} / \mathrm{kg}$ doses, but the number of apoptotic cells of those groups was significantly higher than with the dosages lower than $50000 \mathrm{IU} / \mathrm{kg}$ (Fig. 2, Tab. 1).

When we examined the cell numbers per unit area acquired from Ki67 stained tissue sections, we observed the lowest values in the $200000 \mathrm{IU} / \mathrm{kg}$ and Control groups; and found no difference between these two groups. The control value was lower than the $100000 \mathrm{IU} / \mathrm{kg}$ group. The differences between controls and 10000 $\mathrm{IU} / \mathrm{kg}, 20000 \mathrm{IU} / \mathrm{kg}, 30000 \mathrm{IU} / \mathrm{kg}, 40000 \mathrm{IU} / \mathrm{kg}$ and $50000 \mathrm{IU} / \mathrm{kg}$ were highly significant. There was no statistical difference between the dividing cell numbers per unit area of the $10000 \mathrm{IU} / \mathrm{kg}, 20000$ $\mathrm{IU} / \mathrm{kg}$ and $30000 \mathrm{IU} / \mathrm{kg}$ groups, but their numbers were higher than of the other groups. The number of Ki67 positive cells of 40000 $\mathrm{IU} / \mathrm{kg}$ was statistically higher than in the $200000 \mathrm{IU} / \mathrm{kg}$ group, but was not different from the $50000 \mathrm{IU} / \mathrm{kg}$ and $100000 \mathrm{IU} / \mathrm{kg}$ groups. The cell numbers of the $50000 \mathrm{IU} / \mathrm{kg}$ dosage group were higher than in the $100000 \mathrm{IU} / \mathrm{kg}$ and $200000 \mathrm{IU} / \mathrm{kg}$ groups. The number of dividing cells in the $100000 \mathrm{IU} / \mathrm{kg}$ group was also higher than in the group receiving $200000 \mathrm{IU} / \mathrm{kg}$ (Fig. 3, Tab. 1).

\section{Discussion}

Although there are few sources about the developing rat hippocampus, we have been able to access a few fundamental articles.
Bayer (1980), made extensive studies on the developing rat hippocampus. Bayer reported that the Ammon's horn was primitive on G18-G19. The same study described that axons from subicular neurons formed the fimbria on G18-G19 (19). The author's observations were parallel to our findings. We also defined the primitive Ammon's horn and fimbria in our sections. Reznikov (1991) stated that on G18-G19 the primordial dentate gyrus is formed from ball-like subpial cells. We could also define the primordial dentate gyrus in our sections taken from G19 fetuses (20). In the light of previous studies, we can confirm that our fetuses are 19 days old.

Our results show that $10000 \mathrm{IU} / \mathrm{kg}$ retinyl palmitate given between G10-12 causes an increase in the total number of hippocampal neurons, and higher doses cause a decrease in the total number of neurons in a dose-dependent manner. As expected, at doses that are considered as teratogenic $(100000 \mathrm{IU} / \mathrm{kg}$ and 200000 $\mathrm{IU} / \mathrm{kg}$ ) neuron numbers were further reduced. We know that RA is stimulating cell proliferation and is a necessary substance in brain development $(21,22)$. Our study has shown that $10000 \mathrm{IU} / \mathrm{kg}$ has also increased cell proliferation. This suggests that this amount of retinyl palmitate speeds up development. Our data show that the total neuron numbers from dosages higher than $10000 \mathrm{IU} / \mathrm{kg}$ are lower than the controls. This suggests that dosages beginning from $20000 \mathrm{IU} / \mathrm{kg}$ are affecting the cell number negatively. Previous studies have also reported that high doses of retinoids reduce cell proliferation. Maden et al (1998) have shown that excess vitamin A causes various disorders in the central nervous system through apoptotic mechanisms (23). In another study on adult SpragueDawley rats, they reported that chronic RA administration severely suppressed adult hippocampal neurogenesis (24). Schnorr et al (2011) suggested that subteratogenic doses of RA in pregnancy causes oxidative stress in the brain of mothers and offsprings, and the resulting free radicals cause apoptosis (25).

We determined the number of apoptotic cells in the hippocampus with Tunel staining. Our results confirmed the data of Schnorr et al (25); we observed that apoptosis increased particularly after $50000 \mathrm{IU} / \mathrm{kg}$ and increased further at the doses of $100000 \mathrm{IU} / \mathrm{kg}$ and $200000 \mathrm{IU} / \mathrm{kg}$. The increase of Tunel positive cells may explain the decrease in the total number of neurons as the dose increases. However, the Ki67 labeling, that shows cell proliferation, did not give concordant results with the Tunel data. The number of Ki67 positive cells was only in the $200000 \mathrm{IU} / \mathrm{kg}$ group lower than in controls. Whereas the number of dividing cells of the other groups was greater than the control group, values of dosages of $10000 \mathrm{IU} /$ $\mathrm{kg}, 20000 \mathrm{IU} / \mathrm{kg}$ and $30000 \mathrm{IU} / \mathrm{kg}$ were higher and highly significant compared with all other groups. A study by Appel et al (2019) may shed light on this phenomenon. In this study, they exposed female rats to a high-fat diet after weaning. They applied the same high-fat diet during pregnancy. The 15.5-day-old fetuses of these mothers presented growth retardation, whereas 18.5-day-old offspring of the same group displayed no differences with controls. The authors described this phenomenon as "catch-up growth" and attributed this to increased glucose mobilization regulated by GSK3 $\beta$ (26). According to our present data, we can suggest that a kind of catch-up growth may be present, but the regulating mechanisms of this occurrence need to be investigated. 
When we examined the stereological results as a whole, we saw that the total number of neurons counted particularly in high dosage groups was lower than in the control group, but the cell division is much higher than the controls. Considering the number of apoptotic cells, we suggest that other mechanisms may be effective in the neuron decrease. Griffin et al (2010) used hypothalamic neuron culture in their studies. They added $10 \mu \mathrm{M} 13$-cisRA to the culture and observed that it reduced cell proliferation for 48 hours. They showed that the decrease in cell number was not related to oxidative stress and attributed the reduction of the cell count caused by excess RA not only to apoptosis but also to necrosis and disruption in the cell cycle (27).

\section{Conclusion}

When we assess the data obtained from our study in the light of the abovementioned articles, we can suggest that doses of vitamin A, ranging from $20000 \mathrm{IU} / \mathrm{kg}$ to $50000 \mathrm{IU} / \mathrm{kg}$ and thought to be subteratogenic, may have essentially teratogenic effects during the critical period of embryonic brain development. Even 20000 IU/ $\mathrm{kg}$ of oral vitamin A applied between 10th-12th days of pregnancy causes a decrease in the total number of hippocampal neurons. We suggest that along with apoptosis other mechanisms that decrease cell numbers are effective in the emergence of this result.

\section{References}

1. McCaffery PJ, Adams J, Maden M, Rosa-Molinar E. Too much of a good thing: retinoic acid as an endogenous regulator of neural differentiation and exogenous teratogen. European Journal of Neuroscience 2003; 18 (3): 457-472.

2. Maden M. Retinoic acid in the development, regeneration and maintenance of the nervous system. Nature Reviews Neuroscience 2007; 8 (10): 755-765.

3. Shearer KD, Stoney PN, Morgan PJ, McCaffery PJ. A vitamin for the brain. Trends Neurosci 2012; 35 (12): 733-741.

4. Bremner JD, McCaffery P. The neurobiology of retinoic acid in affective disorders. Prog Neuropsychopharmacol Biol Psychiatry 2008; 32 (2): 315-331.

5. Brown M KR, Lumsden A. The Developing Brain: Oxford University Press; 2004: 1-472.

6. Rhinn M, Dolle P. Retinoic acid signalling during development. Development 2012; 139 (5): 843-858.

7. Goodman T, Crandall JE, Nanescu SE, Quadro L, Shearer K, Ross A, McCaffery P. Patterning of retinoic acid signaling and cell proliferation in the hippocampus. Hippocampus 2012; 22 (11): 2171-2183.

8. Liu Y, Kagechika H, Ishikawa J, Hirano H, Matsukuma S, Tanaka K, Nakamura S. Effects of retinoic acids on the dendritic morphology of cultured hippocampal neurons. J Neurochem 2008; 106 (3): 1104-1116.

9. Bastos Maia S, Rolland Souza AS, Costa Caminha MF, Lins da Silva S, Callou Cruz R, Carvalho Dos Santos C, Batista Filho M. Vitamin A and Pregnancy: A Narrative Review. Nutrients 2019; 11 (3).

10. Holson RR, Gazzara RA, Ferguson SA, Adams J. Behavioral effects of low-dose gestational day 11-13 retinoic acid exposure. Neurotoxicol Teratol 1997; 19 (5): 355-362.
11. Adams J. The neurobehavioral teratology of retinoids: A 50-year history. Birth Defects Research Part A: Clinical and Molecular Teratology 2010; 88 (10): 895-905.

12. Goldberg JS. Monitoring maternal Beta carotene and retinol consumption may decrease the incidence of neurodevelopmental disorders in offspring. Clin Med Insights Reprod Health 2011; 6: 1-8.

13. Adams J. Structure-activity and dose-response relationships in the neural and behavioral teratogenesis of retinoids. Neurotoxicol Teratol 1993; 15 (3): 193-202.

14. Holson RR, Gazzara RA, Ferguson SA, Ali SF, Laborde JB, Adams J. Gestational retinoic acid exposure: A sensitive period for effects on neonatal mortality and cerebellar development. Neurotoxicology and Teratology 1997; 19 (5): 335-346.

15. Keuker JIH, Vollmann-Honsdorf GK, Fuchs E. How to use the optical fractionator: an example based on the estimation of neurons in the hippocampal CA1 and CA3 regions of tree shrews. Brain Research Protocols 2001; 7 (3): 211-221.

16. Weibel ER. Stereological principles for morphometry in electron microscopic cytology. Int Rev Cytol 1969; 26: 235-302.

17. Gundersen HJ, Jensen EB. The efficiency of systematic sampling in stereology and its prediction. J Microsc 1987; 147 (Pt 3): 229-263.

18. Altman JB, S.A. Atlas of Prenatal Rat Brain Development. Boca Raton: CRC Press; 1995: 1-664.

19. Bayer SA. Development of the hippocampal region in the rat. II. Morphogenesis during embryonic and early postnatal life. J Comp Neurol 1980; 190 (1): 115-134.

20. Reznikov KY. Hippocampal Formation in the Mouse and Rat - Structural Organization and Development: A Review. Cell Proliferation and Cytogenesis in the Mouse Hippocampus: Springer, Berlin, Heidelberg; 1991. p. 1-11.

21. Cammas L, Romand R, Fraulob V, Mura C, Dolle P. Expression of the murine retinol dehydrogenase $10(\mathrm{Rdh} 10)$ gene correlates with many sites of retinoid signalling during embryogenesis and organ differentiation. Dev Dyn 2007; 236 (10): 2899-2908.

22. Sandell LL, Sanderson BW, Moiseyev G, Johnson T, Mushegian A, Young K, Rey JP, Ma JX, Staehling-Hampton K, Trainor PA. RDH10 is essential for synthesis of embryonic retinoic acid and is required for limb, craniofacial, and organ development. Genes Dev 2007; 21 (9): 1113-1124.

23. Maden M. The role of retinoids in developmental mechanisms in embryos. Subcell Biochem 1998; 30: 81-111.

24. Hu P, Wang Y, Liu J, Meng FT, Qi XR, Chen L, van Dam AM, Joels M, Lucassen PJ, Zhou JN. Chronic retinoic acid treatment suppresses adult hippocampal neurogenesis, in close correlation with depressive-like behavior. Hippocampus 2016; 26 (7): 911-923.

25. Schnorr CE, da Silva Morrone M, Simoes-Pires A, da Rocha RF, Behr GA, Moreira JC. Vitamin A supplementation in rats under pregnancy and nursing induces behavioral changes and oxidative stress upon striatum and hippocampus of dams and their offspring. Brain Res 2011; 1369: 60-73.

26. Appel S, Grothe J, Storck S, Janoschek R, Bae-Gartz I, Wohlfarth M, Handwerk M, Hucklenbruch-Rother E, Gellhaus A, Dotsch J. A Potential Role for GSK3beta in Glucose-Driven Intrauterine Catch-Up Growth in Maternal Obesity. Endocrinology 2019; 160 (2): 377-386.

27. Griffin JN, Pinali D, Olds K, Lu N, Appleby L, Doan L, Lane MA. 13-Cis-retinoic acid decreases hypothalamic cell number in vitro. Neurosci Res 2010; 68 (3): 185-190.

Received March 1, 2020. Accepted April 6, 2020. 